\title{
SOLIDARITY OF MADURA IMMIGRANTS IN OVERSEAS DESA JEMPARING KECAMATAN LONGIKIS PASER DISTRICT
}

\section{SOLIDARITAS IMIGRAN MADURA DI PERANTAUAN DESA JEMPARING KECAMATAN LONGIKIS KABUPATEN PASER}

\author{
Jafar', Aji Qamara Hakim $^{2}$ \\ ${ }^{1}$ Universitas Mulawarman, Indonesia \\ ${ }^{2}$ Universitas Kutai Kartanegara, Indonesia
}

Email Correspondence: jafar.amir93@gmail.com

\begin{abstract}
:
The purpose of this study was to find out and describe in-depth the Solidarity of Madurese immigrants in Jemparing Village, Long Ikis District, Paser Regency. The research method used in this research is descriptive explorative research. In this research, the researcher wants to explore more deeply related to Madurese ethnic values and norms, leadership systems, community stratification systems, community religious rituals, routine community activities that attach the community, conflict resolution mechanisms within the community and outside the community, mechanisms network building with Madurese ethnic communities in other areas and solidarity with Madurese immigrants in Jemparing Village using Emile Durkheim's theory of organic solidarity and mechanical solidarity. The results showed that the Solidarity of Madurese Immigrants in Perantau, Jemparing Village, Long Ikis District, Paser Regency, was going well, meaning that the solidarity that was built was quite solid. This is based on the patterns of interaction that are built between fellow Madurese ethnicities and with the surrounding community through several methods. Also, to be accepted in the local community, Madurese immigrants who are in Jemparing Village try to accept the customs/culture of the local community as a process of assimilation but do not forget their local customs/culture. Apart from that, organic solidarity and mechanical solidarity can go hand in hand in the daily life of Madurese immigrants who are in Jemparing Village, to be precise in the Ombe area.
\end{abstract}

\section{Keywords: Madurese Immigrants, Social Interaction, Solidarity}

\begin{abstract}
ABSTRAK:
Tujuan dari penelitian ini adalah untuk mengetahui dan menggambarkan secara mendalam mengenai Solidaritas Imigran Madura di Perantauan Desa Jemparing Kecamatan Long Ikis Kabupaten Paser.Metode penelitian yang peneliti gunakan pada penelitian kali ini yaitu jenis penelitian deskriptif exsploratif. Pada penelitian kali ini peneliti ingin mengexsplor jauh lebih dalam terkait dengan nilai dan norma Etnis Madura, sistem kepemimpinan, system stratifikasi komunitas, ritual-ritual keagamaan komunitas, kegiatan-kegiatan rutin komunitas yang melekatkan komunitas, mekanisme penyelesaian konflik dalam komunitas dan luar komunitas, mekanisme pembangunan jaringan dengan komunitas Etnis Madura di wilayah lain dan solidaritas Imigran Madura di Desa Jemparing dengan menggunakan teori dari Emile Durkheim tentang solidaritas organik dan soldaritas mekanik. Hasil penelitian menunjukkan bahwa Solidaritas Imigran Madura di Perantauan Desa Jemparing Kecamatan Long Ikis Kabupaten Paser berjalan dengan baik, artinya bahwa solidaritas yang terbangun cukup solid. Hal itu berdasar pada pola interaksi yang dibangun baik antar sesama etnis Madura maupun dengan masyarakat sekitar melalui beberapa metode. Selain itu untuk dapat diterima dalam masyarakat setempat Imigran Madura yang berada di Desa Jemparing mencoba menerima adat-istiadat/budaya masyarakat setempat sebagai proses pembauran, tetapi tidak melupakan adat-istiadat/budaya local mereka. Selain itu solidaritas organik dan solidaritas mekanik dapat berjalan beriringan di dalam kehidupan sehari-hari Imigran Madura yang berada di Desa Jemparing, tepatnya di wilayah Ombe.
\end{abstract}

Kata Kunci: Imigran Madura, Interaksi Sosial, Solidaritas

\section{Article Info}

Received

Accepted

Published

DOI
: July 2020

: July 2020

: July 2020

: https://doi.org/10.30872/psd.v1i2.19

Copyright and License

Authors retain copyright and grant the journal right of first publication with the work simultaneously licensed under a Creative Commons Attribution 4.0 International License that allows others to share the work with an acknowledgment of the work's authorship and initial publication in this journal. 


\section{PENDAHULUAN}

Pulau Madura merupakan salah satu pulau yang terletak di wilayah Jawa Timur dengan komposisi penduduk mencapai 12 juta jiwa pada tahun 2010 dan tersebar sebagian besar di beberapa wilayah di nusantara antara lain, Kalimantan, Papua, Jakarta, bahkan sampai ke Negara tetangga seperti Malaysia dan Singapura. Persebaran penduduk Madura tersebut tidak tanpa alasan. Hal ini berkaitan dengan kondisi geografis daripada kepulauan Madura itu sendiri. Sebagaimanayang diketahui bahwa hampir seluruh daratan Pulau Madura merupakan tanah tegalan, dan tandus sehingga tidak produktif secara ekonomis. Hal ini, secara tidak langsung membentuk karakter daripada masyarakat Madura yang keras, dan pantang menyerah untuk bertahan hidup. Sebab sulitnya pekerjaan yang dicari mengaharuskan masyarakat Madura berpikir keras untuk dapat bertahan. Hal ini pula yang menyebabkan sebagian besar masyarakat Madura melakukan migrasi ke beberapa daerah/wilayah yang dianggap memiliki sumber daya alam yang melimpah serta peluang kerja yang lebih besar semata-mata untuk memperbaiki kualitas hidup. Salah satu daerah yang dinggap potensial adalah Pulau Kalimantan.

Persebaran penduduk Madura di Kalimantan pada tahun 2000 mencapai angka berkisaran 350 ribu jiwa. Di provinsi Kalimantan Barat 205.550 jiwa, Kalimantan Tengah 62.228 jiwa, Kalimantan Selatan 36.334 jiwa, Kalimantan Timur dan Utara 30.118 jiwa. Namun pada tahun 2010, sensus penduduk mencatat kembali jumlah Imigran Madura yang berada di Kalimantan mencapai angka 517.204 jiwa. Kalimantan Barat 274.869 jiwa, Kalimantan Tengah 42.668 jiwa, Kalimantan Selatan 53.002 jiwa, serta Kalimantan Timur dan Kalimantan Utara 46.668 jiwa. Dari data di atas dapat dilihat bahwa peningkatan jumlah imigran Madura terjadi di provinsi Kalimantan Selatan, Kalimantan Barat, dan Kalimantan Timur dan Utara. Penurunan jumlah Imigran Madura hanya terjadi terjadi di provinsi Kalimantan Tengah.

Penurunan jumlah Imigran Madura di Kalimantan Tengah ini tentu berkaitan dengan peristiwa sampit yang terjadi pada tahun 2001 silam. Peristiwa tersebut merupakan konflik yang terjadi antara etnis Dayak dan Madura. Dari data yang diambil dari Komisi Nasional Hak Asasi Manusia, korban jatuh mencapai 400 jiwa, 319 lebih rumah dibakar, dan sekitar 197 lainnya dirusak serta 45 ribu warga Madura dievakuasi. Peristiwa tersebut menjadi salah satu peristiwa pertikaian terbesar anta retnis di Indonesia. Dari berbagai sumber mengatakan bahwa faktor penyebab terjadinya konflik tersebut berasal dari terjadinya ketimpangan ekonomi antara kaum pendatang dan pribumi, gesekan-gesekan budaya antar kedua etnis serta kolonialisasi masyarakat pendatang atas masyarakat pribumi.

Akhirnya sreteotip pun melekat pada etnis Madura sebagai etnis yang suka merebut tanah orang, etnis yang tidak tahu berterimakasih, serta etnis yang kasar/keras. Selain itu Etnis Madura ketika di perantauan memiliki kecendrungan untuk hidup berkelompok serta membangun solidaritas kelompoknya. Hal ini tentu sebagai wujud proteksi diri dalam sistem sosial dalam masyarakat, mengingat bahwa sebelumnya pernah terjadi konflik antara Etnis Madura dengan etnis asli di Kalimantan. Hal inilah yang terjadi pada masyarakat Madura yang berada di Desa Jemparing Kecamatan Long Ikis Kabupaten Paser. Di mana peneliti melihat bahwa hampir 97\% pekerja pemecah batu adalah imigran yang berasal dari Madura. Selain itu, identitas lokal daerah asal masih terlihat begitu kental, seperti perayaan maulid Nabi Muhammad SAW, kajian-kajian keagamaan, serta perayaan datangnya bulan safar. Hal lain yang peneliti lihat adalah, Imiran Madura yang berada di wilayah tersebut terpisah daripada kehidupan masyarakat asli setempat. Secara tidak langsung peneliti melihat, hal ini sebagai upaya membangun solidaritas kelompoknya di perantauan serta sebagai proteksi dari masyarakat sekitar. Inilah kemudian yang menarik peneliti untuk dapat melihat lebih dalam mengenai Solidaritas Imigran Madura di Desa Jemparing Kecamatan Long Ikis Kabupaten Paser.

\subsection{Solidaritas Sosial}

Menurut Kamus Besar Bahasa Indonesia pengertian kata solidaritas adalah, sifat (perasaaan) solider, sifat satu rasa (senasib), perasaan setia kawan yang pada suatu kelompok anggota wajib memlikinya (Depdiknas, 2007:1082). Menurut Kamus Besar Bahasa Indonesia arti kata sosial adalah berkenaan dengan masyarakat, perlu adanya komunikasi dalam usaha menunjang pembangunan, suka memperhatikan umum (Depdiknas, 2007:1085). Sementara itu menurut Nasution (2009:3) bahwa solidaritas sosial adalah perasaan secara kelompok memiliki nilai-nilai yang sama atau kewajiban moral untuk memenuhi harapan harapanharapan peran. Pengertian mengenai solidaritas sosial diperjelas oleh Durkheim (dalam Lawang, 1994:181) yang menyatakan bahwa solidaritas sosial merupakan suatu keadaan hubungan antara individu dan atau kelompok yang didasarkan pada perasaan moral dan kepercayaan yang diaut bersama dan diperkuat oleh pengalaman emosional. Solidaritas menekankan pada keadaan hubungan antar individu dan kelompok dan mendasari keterikatan bersama dalam kehidupan dengan didukung nilai-nilai moral kepercayaan yang hidup di dalam masyarakat.

Progress in Social Development: Volume 1 No 2 Juli 2020 


\subsection{Solidaritas Mekanik.}

Menurut Durkheim, solidaritas mekanik didasarkan pada suatu '"kesadaran kolektif' bersama (collective consciousness/conscience), yang menunjuk pada "totalitas kepercayaan-kepercayaan dan sentimen-sentimen bersama yang rata-rata ada pada warga masyarakat yang sama itu". (Durkheim dalam Johnson, 1986:183). Ikatan utamanya adalah kepercayaan bersama, citacita, dan komitmen moral. Oleh karena itu, maka individualitas tidak dapat berkembang dan bahkan terus-menerus dilumpuhkan oleh tekanan yang besar

sekali untuk komformitas.

\subsection{Solidaritas Organik}

Solidaritas sosial yang berkembang pada masyarakat-masyarakat kompleks berasal lebih dari kesalingtergantungan daripada dari kesamaan bagianbagian (Campbell,1994:185). Lebih jelasnya, Johnson (1986:183) menguraikan bahwa solidaritas organik muncul karena pembagian kerja bertambah besar. Solidaritas itu didasarkan pada tingkat saling ketergantungan yang tinggi. Saling ketergantungan itu bertambah sebagai hasil dari bertambahnya spesialisasi dan pembagian pekerjaan yang memungkinkan dan juga menggairahkanbertambahnya perbedaan dikalangan individu. Munculnya perbedaan-perbedaan dikalangan individu ini merombak kesadaran kolektif itu, yang pada akhirnya menjadi kurang penting lagi sebagai dasar untuk keteraturan sosial dibandingkan dengan saling ketergantungan fungsional yang bertambah antara individuindividu yang memiliki spesialisasi dan secara relatif lebih otonom sifatnya.

Selain itu, dalam masyarakat dengan solidaritas organik tingkat heterogenitas semakin tinggi, karena masyarakat semakin plural. Penghargaan baru terhadap kebebasan, bakat, prestasi dan karir individual menjadi dasar masyarakat pluralistik.

\subsection{Sifat-sifat Pokok Solidaritas}

a. Solidaritas Mekanik

1. Pembagian kerja rendah

2. Kesadaran kolektif kuat

3. Hukum represif dominan

4. Konsensus terhadap pola-pola normatif penting

5. Individualitas rendah

6. Keterlibatan komunitas dalam menghukum orang yang menyimpang

7. Secara relatif saling ketergantungan itu rendah

8. Bersifat primitif atau pedesaan

b. Solidaritas Organik

1. Pembagian kerja tinggi

2. Kesadaran kolektif lemah

3. Hukum restitutif dominan

4. Konsensus pada nilai-nilai abstrak dan umum penting

5. Individualitas tinggi

6. Badan-badan kontrol sosial yang menghukum orang-orang yang menyimpang

7. Saling ketergantungan yang tinggi

8. Bersifat industrial perkotaan

\subsection{Unsur-unsur Pembentuk Solidaritas}

1. Kesatauan Genealogis atau Faktor Keturunan

Kesatuan Genealogis merupakan salah satu yang yang menjadi unsurdalam membangun solidaritas suatu kelompok. Solidaritas yang dibangaun berdasarkan kesamaan keturunan mampu membuat suasana kelompok sosial lebih mengarah pada arah persaudaraan. Karena kesamaan keturunan mampu memberikan komitmen yang kuat dalam kelompok sosial agar tidak terputus tali persaudaraannya.

2. Kesatuan Religius

Setiap agama sudah pasti memiliki atauran-atauran dalam hidup bermasyarakat ataupun berkelompok. Aturan-aturan tersebut tertuang dalam sebuah nilai dan norma. Nilai dan norma inilah yang kemudian mengatur setiap gerak-gerik tingkah laku manusia. Tentu hal yang sangat ideAl menjadikan kesamaan agama sebagai pemersatu dalam membentuk suatau kelopok sosial dalam membangun solidaritas sosial. 


\section{Kesatuan Teritorial (Community)}

Terbentuknya suatu kelompok sosial dalam membangun solidaritas yang kuat tentu pula didasari karena adanya kesamaan suatau wilayah atau sering kita sebut dengan persamaan primordial (kedaeraan). Di dalam kesamaan primordial sudah pasti nilai-nilai serta norma-norma yang dianut akan sama. Hal ini akan lebih mudah dalam membangun pola interaksi dalam sebuah kelompok sosial.

4. Kesatuan Kepentingan (Asosiasi)

Tentu persamaan kepentingan dapat mempermudah tercapainya cita-cita bersama. Karena pada dasarnya individu-individu memiliki keingainan yang inginn dicapai. Oleh karena itu bergabung bersama dengan orang-orang yang memiliki persamaan kepentingan, akan jauh lebih mudah untuk mencapainya.

\section{METODE}

Dalam penelitian ini peneliti menggunakan pendekatan kualitatif deskripstif exsploratif. Di mana menurut Bogyan dan Taylor metode penelitian kualitatif adalah prosedur penelitian yang menghasilkan data diskriptif berupan kata-kata tertulis atau lisan dari orang-orang dan perilaku yang dapat diamati. Dasar penulis ingin menggunakan penelitian kualitatif adalah bahwa peniliti ingin mengetahui secara lebih mendalam mengenai 'Solidaritas Imigran Madura di Perantauan Desa Jemparing Kecamatan Long Kali Kabupaten Paser'. Dilihat dari aspek tujuan penilitian ini adalah penelitian exsploratif. Penelitian exsploratif adalah penelitian yang bertujuan menggali secara luas mengenai sebab-sebab atau hal-hal yang mempengarui terjadinya sesuatu. Asumsi peneliti menggunakan penelitian exsploratif adalah bahwa peneliti ingin menggali secara lebih luas mengenai mekanisme 'Solidaritas Imigran Madura di Perantauan'. Maka dalam hal ini peneliti mempelajari bagaimana Imigran Madura membangun solidaritasnya di perantauan sebagai kekuatan sosial. Peneliti dapat mempelajari kekuatan dari solidaritas tersebut dengan mengetahui dan menganalisis, proses dalam membangun solidaritas di perantauan melalui perilaku kelompok, aktivitas kelompok, nilai dan norma, serta mekanisme-mekanisme dalam membangun soldiaritas dari para Imigran Madura yang berada di Desa Jemparing.

\subsection{Gambaran Umum Desa Jemparing dan Imigran Madura Desa Jemparing}

Desa Jemparing merupakan salah satu desa yang berada di wilayah Kecamatan Long Ikis. Jemparing memiliki luas wilayah kurang lebih 8.750 Ha yang terdiri 12 Rukun Tetangga (RT) yang terbagi menjadi 2 dusun. Dusun satu mencakup RT 01, 02, 03, 04 dan 05 sedangkan dusun dua mencakup RT 06, 07, 08, 09 dan 10. Selain itu Desa Jemparing berada pada 116o 150 31,0 bujur timur (BT) dan 010330 36, 3 lintang selatan (LS), dengan keadaan alam berbukit dengan ketinggian 100 s/d 300 meter dari permukaan laut. Selain itu untuk jumlah keseluruhan penduduk di Desa Jemparing menurut data monografi Desa Jemparing pada tahun 2014 yaitu 1794 jiwa yang terdiri dari jenis kelamin laki-laki sebanyak 962 jiwa dan perempuan sebanyak832 jiwa dengan total jumlah Kartu Keluarga (KK) 439.Sedangkan pada tahun 2015 jumlah penduduk mengalami peningkatan yang tidak terlalu besar. Data monografi Desa Jemparing tahun 2015 menjelaskan bahwa penduduk pada tahun 2015 yaitu 1819 jiwa dengan jenis kelamin laki-laki sebanyak 979 jiwa dan perempuan 839 jiwa dengan total Kartu Keluarga (KK) 546.

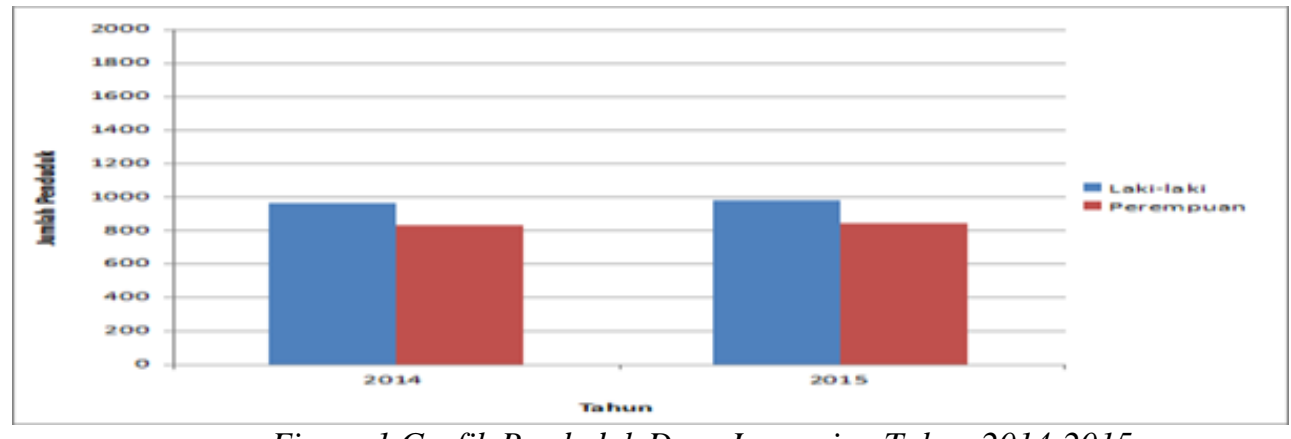

Figure 1 Grafik Penduduk Desa Jemparing Tahun 2014-2015

\section{Sumber : Data Monograf Kantor Desa Jemparing Tahun 2015}

Selanjutnya untuk persebaran penduduk di Desa Jemparing terdiri dari beberapa etnisitas. Diantara etnis tersebut yaitu Pasir, Bugis, Jawa, Padang, NTB, NTT, Banjar, Sunda, dan Madura. Dari jumlah etnis tersebut persentase terbesar berdasarkan etnisitas ditempati oleh etnis Paser, disusul dengan Madura, Jawa, Bugis, Sunda, Banjar, Padang, NTB, dan NTT. Untuk lebih jelasnya terkait dengan jumlah persentase etnisitas lihat tabel 4. 2 di bawah ini 


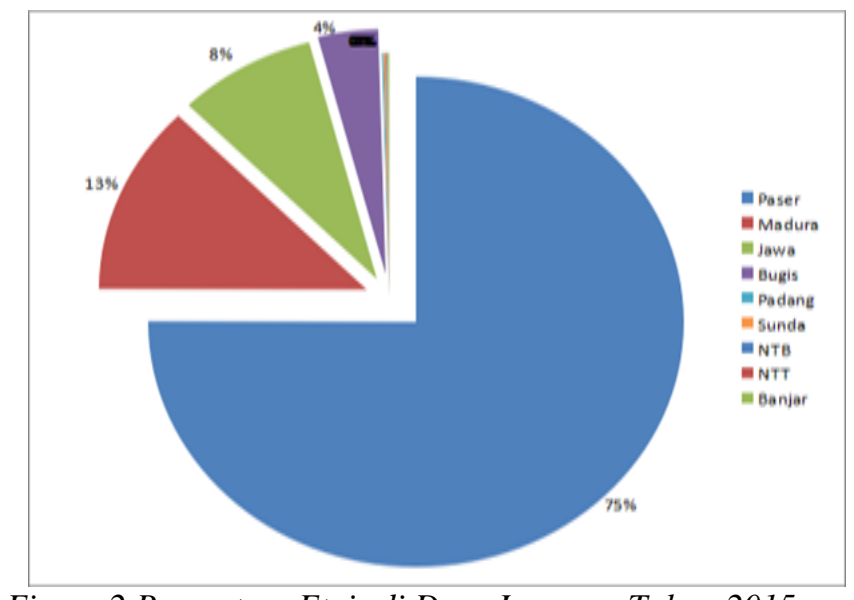

Figure 2 Prosentase Etnis di Desa Jempang Tahun 2015

\section{Sumber : Data Monograf Kantor Desa Jemparing Tahun 2015}

\subsection{Imigran Madura}

Lokasi Imigran Madura yang berada di Desa Jemparing berada di RT 06, dusun 2 tepatnya berada di lokasi bahan galain $\mathrm{C}$ wilayah Ombe. Kepala Adat dari masyarakat Madura yang berada di lokasi tersebut yaitu Bapak Ahmad Matori. Jarak yang harus ditempuh untuk menuju lokasi Ombe (Kampung Madura) kurang lebih 4-6 kilo, dengan jarak tempuh waktu sekitar 15-20 dengan akses jalan yang masih rusak. Berikut penulis tampilkan akses jalan menuju Kampung Madura di lokasi Ombe :

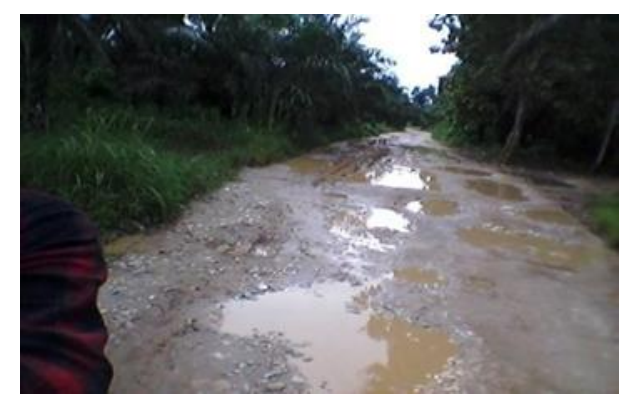

Figure 3 Kondisi Akses Menuju Lokasi

\section{Sumber : Dokumentasi Peneliti}

\section{HASIL DAN PEMBAHASAN}

Solidaritas Imigran Madura di Perantauan Sesuai dengan tujuan dari penelitian ini bahwa peneliti ingin melihat solidaritas Imigran Madura di perantauan dari tujuh nilai, nilai-nilai tersebut antara lain, yaitu nilainilai Etnis Madura, sistem kepemimpinan, sistem stratifikasi komunitas, ritual keagamaan komunitas, kegiatan rutin komunitas lain yang melekatkan komunitas, penyelesaian konflik dalam dan luar komunitas, mekanisme pembangunan jaringan dengan Etnis Madura di wilayah lain dan solidaritas Imigran Madura di Desa Jemparing

\subsection{Nilai-nilai Etnis Madura}

a. Ajaran Tentang Kehidupan

Bagi masyarakat Madura ajaran tentang kehidupan merupakan perpaduan antara kehidupan dunia dan akhirat. Hidup dunia dan akhirat harus berjala secara berimbang. Sebab sebagai insan, atau manusia diwajibkan untuk selalu menggunakan karunia yang berikan Tuhan pada dirinya. Terutama yaitu akal. Sebab hanya akal yang kemudian mampu menilai mana yang benar dan salah. Selain itu hidup adalah perjuagan, artinya dalam menjalankan hidup tidak pantas untuk putus asa ataupun menyerah.

b. Ukuran Kegagalan Dalam Hidup

Gagal dalam bahasa Indonesia dapat di artikan sebagai keinginan atau cita-cita yang kemudian tidak dapat di wujudkan atau dicapai yang di sebabkan karena faktor material maupun inmaterial. Gagal dalam hidup, berarti apa yang dimpikan sebagai dari tujuan hidup sendiri tidak mampu terpenuhi. Setiap golongan, etnis suku ataupun agama lainnya memiliki indikator tersendiri kegagalan dalam hidup yang kemudian mereka yakini dan jalani. Begitu pula dengan Etnis Madura. Dalam hidup ini, mereka meyakini bahwa orang- 
orang Madura yang gagal dalam hidup adalah mereka yang tidak mampu menggunakan akal dan pikirannyaa dalam bertindak, dan hanya fokus untuk mencari harta dunia saja.

c. Nilai Pembauran yang Diterapkan di Perantauan

Nilai merupakan hasil daripada produk sosial yang kemudian menjadi landasan atau ukuran dalam berbuat dan bertindak. Nilai sering kali dijadikan sebagai pedoman bagi masyarakat ataupun kelompok sosial dalam menjalankan tatanan di dalam masyarakat. Menurut Spranger (Muhammad Ali, 2010) nilai adalah suatu tatanan yang dijadikan panduan oleh individu ataupun kelompok untuk menimbang dan memilih alternative keputusan dalam situasi sosial tertentu. Hal ini ini sesuai dengan apa yang para Imigran Madura terapkan di Desa Jemparing. Dengan membawa tekanan dari perspektif masyarakat yang mengataka bahwa "Jangan berteman baik dengan orang Madura“. Menjadikan orang-orang Madura untuk dapat mempelajari dan menerima nilai-nilai yang ada di masyarakat Desa Jemparing agar memudahkan dalam proses pembauran dan interaksi.

\subsection{Sistem Kepemimpinan}

a. Karakteristik Pemimpin dan Orang yang Paling Dihormati/Segani

Pemimpin yang baik atau ideal adalah seorang yan memiliki kredibilitas, stabilitas serta kapabilitas yang mempenghuni. Dalam hal ini pula Etnis Madura memiliki kreteria tersendiri bagi kelopomknya untuk dapat dijadikan seorang pemimpin dalam suatu kelompok atau komunitas tertentu. Tentunya hal ini untuk menjaga stabilitas atau keseimbagan dalam tatanan sosial. Pemimpin bagi Etnis Madura harus dilihat dari aspek ilmu, agama, status sosial serta kewibawaannya.

b. Kyai bagi Etnis Madura

Bagi Etnis Madura sendiri, 'Kyai' merupakan sosok yang paling dihormati/disegani di dalam tatanan kehidupan sosial masyarakat Madura. Sebab masyarakat Madura percaya bahwa 'Kyai' adalah sosok yang kemudian dapat menyelamatkan kehidupan dunia dan akhirat. Oleh karenanya, segala macam permasalahan baik urusan dunia maupun akhirat, 'Kyai' lah tempat mereka mencari solusi.

\subsection{Sistem Stratifikasi Komunitas}

Pada umumnya stratatifikasi yang terjadi di dalam masyarakat terbagi menjadi dua bagian, yaitu stratifikasi sosial yang sifatnya tertutup, dan stratifikasi sosial yang sifatnya tertbuka. Stratifikasi sosial yang sifatnya tertutup dapat diartikan bahwa, setiap anggota/individu tidak bisa pindah ke tingkatan sosial yang lebih tinggi. Dia hanya akan berada pada posisi lapisan yang dia miliki sekarang hingga nanti tak pernah berubah. Contoh daripada pola ini yaitu yang terjadi pada sistem kasta masyarakat hindu. Selanjutya stratifikasi sosial yang sifatnya terbuka diartikan bahwa setiap anggota/individu dapat berpindah dari setiap tingkatan satu ketingkatan lainnya. Dalam hal ini, bisa terjadi karena faktor pendukung seperti kekayaa, ilmu pengetahuan, jabatan, serta penghargaan. Lalu bagaimanana dengan sistem stratifiksi Etnis Madura? Menurut peneliti stratifikasi yang terjadi di Etnis Madura bersifat terbuka, sebab pada dasarnya ketika menjadikan seorang pemimpin dalam suatu kelompoknya, tidak terlepas daripada unsure status sosialnya, dalam hal ini dapat dilihat dari kekayaannya.

\subsection{Ritual-ritual Keagamaan Komunitas}

a. Ritual Keagamaan sebagai Perekat Sesama Imigran Madura

Kata agama sendiri berasal dri bahasa sanksekerta yang berarti 'tradisi'. Sedangkan kata latinnya terdiri dari kata le-ligare yang berarti mengikat kembali. Hal ini menyatakan bahwa orang yang beragama adalah orang yang menghambakan dirinya pada Tuhan-Nya. Agama pada dasarnya tidak dapat dipisahkan dengan budaya. Agama terkadang mengikuti pola-pola tradisi/budaya masyarakat setempat. Hal ini menjelaskan bahwa agama itu bersifat fleksibel dan tidak ruwet. Hal inilah yang kemudian diterapkan oleh para wali songo dalam menyebarkan Agama Islam di tanah Jawa pada masa silam. Hinggah kini tradisi itupun masih berlangsung. Salah satunya yaitu tradisi atau budaya untuk kajian keagamaan sebagai salah satu perekat hubugan yang dilakukan oleh Etnis Madura di manapun mereka berada. Contohnya adalah Etnis Madura yang berada di Desa Jemparing yang peneliti teliti. Etnis Madura yang berada di Desa Jemparing pada hari-hari tertentu juga melaksankan kajian-kajian keagamaan tersebut.

b. Kajian Keagamaan Bersama Masyarakat Setempat

Imigran Madura yang berada di Desa Jemparing selain melakukan kajian keagamaan bersama dalam kelompoknya, juga melakukan perluasan kajian bersama dengan masyarakat setempat. Hal ini dilakukan setelah konflik yang terjadi antara Etnis Madura dengan Etnis Paser pada tahun 2008 silam. Hal ini bertujuan untuk membangun kembali hubungan antar kedua etnis pasca konflik. Selain itu pula hal ini dilakukan sebagai upaya penyebaran nilai-nilai Islam kepada masyarakat setempat. Ini dilakukan mengingat bahwa hampir keseluruan masyarakat Jemparing masih kental akan animisme dan dinamisem walaupun semua 
beragama Agama Islam. Sebagaimana yang ditahu bahwa sebagian masyarakat setempat masih kental dengan hal yang terkait dengan animisme ataupun dinasmisme walaupun sebenarnya rata-rata masyarakat setempat memeluk Agama Islam. Walaupun dengan sterotip yang buruk yang melekat pada Etnis Madura, merek mencoba untuk membuktikan bahwa, apa yang selama ini melekat pada etnis mereka terkait dengan steorotip buruk, tidak selalu benar adanya. Hasil daripada aktivitas yang dilakukan Etnis Madura tersebut membawa dampak positif bagi kelompok mereka, alhasil etnis mereka sejauh ini diterima oleh masyarakat Jemparing hingga saat ini.

\subsection{Kegiatan Rutin Komunitas Lain yang Melekatkan Komunitas}

a. Kegiatan Individu dalam Membangun Silahturahim Sesama Imigran Madura di Peratauan

Ketika berada di perantauan masyarakat Madura selalu menjaga hubungan kekeluargaan karena ikatan primordial. Hal ini disebabkan karena bagi masyarakat Madura, mereka tidak mau melihat sesama saudara yang berada di perantauan merasa terisolasi atau teransingkan dan kesepian. Oleh karenanya setiap Imigran Madura yang baru merantau ke suatu daerah, akan diterima dengan sangat terbuka, sebagai wujud simpatisan sesama orang Madura. Selain itu hal yang lain dilakukan untuk meningkatkan kesolidatan antar kelompok mereka(orang Madura), biasanya melakukan kunjungan sekedar silahturahim di masa- masa senjang aktivitas.

b. Penggalangan Dana Ketika Sesama Imigran Madura Mengalami Musibah

Penggalangan dana yang dilakukan oleh sesama Imigran Madura ketika saudaranya mengalami sakit atau mendapatkan musibah ada dilakukan di Desa Jemparing. Biasanya yang menjadi kordinator adalah kepala pekerja masing- masing. Pada saat salah satu pekerjanya mendapatkan kecelakaan kerja atau musibah. Masing-masing dari kepala pekerja berkumpul dan membicarakan hal tersebut secara terbuka. Ketika masalahnya kecil maka hanya kepala kepala pekerja saja yang berkumpul. Namun ketika masalah tersebut besar, biasanya kepala pekerja mengumpulkan juga para pekerjanya beserta kordinator pengurus Imigran Madura di daerah tersebut. Ini merupakan salah satu wujud kesolidtan antar sesama mereka. Namun bantuan dana yang dikumpulkan biasanya meyesuaikan dengan kemampauan masing-masing para pekerja. Bantuan dana bisanya lebih banyak diberikan oleh kepala pekerja.

c. Mencari Bantuan Ketika Mengalami Jalan Buntu dalam Permasalahan

Dalam hidup ini tentu saja akan datang suatu saat masalah ataupun musibah dalam kehidupan kita. Hal itu mutlak terjadi, dan tidak dapat dihindari. Hanya saja, proses terjadinya yang kemudian akan berbeda dengan yang lainnya. Bisa bersifat individu maupun bersifat kelompok (sosial). Tentu saja tidak semua permasalahan kemudian dapat dislesaikan denga mudah. Ada masaslah-masalah yang sulit untuk diselesaikan karena beberapa faktor. Hal ini berlaku secara umum. Begitu pula yang terjadi dengan Etnis Madura yang berada di Desa Jemparing. Ketika kelompok mereka (Etnis Madura) mendapatkan suatu masalah dalam komunitasnya, mereka tentunya akan menyelesaikan berdasarkan aturan aturan yang telah ditetapkan dalam kelompoknya. Namun bila masalah yang terjadi diluar komunitasya, tentu saja metode penyelesaiannya akan berbeda. Biasanya ketika masalah berada di luar komunitasnya, terjadi mediasi antar ketua dari masyarakat Madura dengan sesepuh kampung setempat (jika permasalahan menyangkut kedua etnis).

\subsection{Mekanisme Penyelesaian Konflik dalam dan luar Komunitas}

a. Mekanisme Penyelesaian Konflik Etnis Madura dengan Etnis Paser

Ketegangan atau konflik antara Etnis Madura dengan etnis luar (Paser) di Desa Jemparing pernah terjadi pada tahun 2008. Penyebab konflik karena kesalapahaman antara kedua pemuda Desa tersebut pada saat malam pembagian hadiah kegiatan 17 Agustusan. Pemuda dari Etnis Paser pada saat melakukan pembersihan tempat acara setelah kegiatan selesai, tidak sengaja pada saat mengangkat kursi, mengenai anak dari salah satu pemuda Madura. Melihat anaknya menangis seketika, pemuda Madura tersebut mengacungkan celurit ke hadapan pemuda Paser tersebut, dan suasana seketika menjadi tegang antar kedua etnis tersebut, terutama golongan pemuda-pemuda. Namun hal tersebut tidak sempat menimbulkan pertumpahan darah atau menyebabkan korban jiwa dari kedua pihak.

Karena seketika ditengahkan dari Tokoh Adat Paser di desa tersebut. Merasa di rendahkan atau dihina, pemuda-pemuda Paser tidak terima, esoknya Etnis Madura dikepung oleh Etnis Paser yang berasal dari berbagai wilayah, diantaranya, Sepaku, Long Kali, Grogot, Sotek, dan kelompok Ormas Gepak, karena berita tersebut setelah kejadin tersebar kebeberapa wilayah di daerah Paser dan Penajam Paser Utara. Terlepas dari itu, penyebab konflik juga karena disebabkan karena perbedaan budaya antar kedua etnis tersebut. Karena bagi masyarakat Madura membawa celurit pada saat bepergian kemana-mana merupakan hal yang biasa atau bahkan sudah menjadi budaya Etnis Madura, namun bagi orang Paser hal tersebut tidak pantas dan mengisyaratkan untuk menantang untuk berdual, karena itu telah terjadi mist budaya antar kedua etnis tersebut. Akhirnya dari peristiwa tersebut masyarakat Madura dikenakan denda, berupa denda adat, yaitu 
melaksanakan upacara belian dengan memotong sapi satu ekor dilapangan dan diramaikan bersama dari kedua etnis.

b. Hubungan Etnis Madura dan Etnis Paser Pasca Konflik

Konflik yang terjadi pada tahun 2008 silam antar Etnis Madura dengan Etnis Paser tentu membuat bekas yang dalam terutama bagi Etnis Madura sebagai etnis pendatang. Namun hal tersebut tidak menjadikan Etnis Madura menutup diri bahkan mengasingkan diri dari lingkungan masyarakat di Desa Jemparing. Justru setelah terjadinya konflik tersebut Etnis Madura mencoba lebih terbuka dan fleksibel terhadap perlakuan masyarakat setempat. Dalam artian, bahwa Etnis Madura lebih bisa membaur dan bersatu dengan masyarakat setempat. Tentu saja hal tersebut tidaklah mudah apalagi setelah terjadinya konflik. Namun tekad kuat dari kelompok Etnis Madura untuk dapat di terima kembali membuahkan hasil. Terbukti, sejak terjadinya konflik pada tahun 2008 silam hinggah kini ketegangan besar antar kedua belah etnis belum pernah terjadi. Hal tersebut menandakan bahwa sejauh ini hubungan pasca konflik berjalan dengan baik yang ditandakan dengan dijalankannya progam kajian bersama antar etnis, kegiatan olahraga bersama dan berkumpul bersama (nongkrong).

\subsection{Mekanisme Pembangunan Jaringan dengan Etnis Madura di Wilayah Lain}

Pembangunan jaringan yang dilakukan pada umumnya dimaksudkan sebagai perekat atau penguat hubungan yang terjadi dari berbagai pihak. Hal ini tentu saja tidak terlepas dari kepentingan-kepentingan yang ada dari setiap individu maupun kelompok. Kepetingan dalam hal ini, bisa bersifat politis, sosial maupun ekonomis. Dalam hal ini, kaitan dengan penelitian yang peneliti lakukan terhadap Imigran Madura yang berada di Desa Jemparing didapatkan bahwa ternyata dalam dalam hal pembangunan jaringan antar wilayah dilakukan semata- mata bersifat politis.

\subsection{Solidaritas Mekanik dan Solidaritas Organik Masyarakat Imigran Madura di Desa Jemparing}

Berdasarkan teori dari Emile Durkheim mengenai solidaritas mekanik dan solidaritas organik. Durkheim mengatakan bahwa solidaritas mekanik adalah sebuah solidaritas yang dihubungkan karena adanya kesadaran kolektif yang diikat karena totalitas kepecayaan, cita-cita bersama, komitmen moral, homogenitas yang tinggi, serta hukum bersifat represif. Pada masyarakat Imigran Madura di Desa Jemparing, hubungan yang terjalin diantara mereka dilihat dari konsep solidaritas mekanik Durkheim disebabkan karena adanya kesamaan nilai (totalitas kepercayaan yang sama), ikatan etnisitas dan primordial, satu homogenitas, hukum masih bersifat represif serta adanya rasa senasib dan sepenanggunggan (penggalangan dana ketika kerabat mengalami musibah). Sedangkan solidaritas organik merupakan sebuah hubungan yang dibangun karena adanya satu kepentingan bersama, heterogenitas, individualitas yang tinggi, serta adanya pembagian kerja.

Pada masyarakat Imigran Madura yang berada di Desa Jemparing dilihat dari solidaritas organiknya disatukan karena adanya kepenetingan yang sama untuk mencari nafkah di perantauan dan kepentingan pekerjaan. Menurut Durkheim bahwa solidaritas mekanik dan solidaritas organik tidak dapat disatukan. Solidaritas mekanik terjadi pada masyarakat yang masih sederhana (desa) dan tidak ada pembagian kerja. Sedangkan solidaritas organik terjadi pada masyarakat yang kompleks (kota) dan telah memiliki spesialisasi pekerjaan personal. Namun temuan di lapangan tidak seperti apa yang kemudian dijelaskan oleh Emile Durkheim mengenai konsep solidaritas mekanik dan solidaritas organiknya. Pada masyarakat Imigran Madura di Desa Jemparing, mereka disatukan oleh solidaritas mekanik dan solidaritas organik di dalamnya. Ini menandakan bahwa dalam ilmu sosial perubahan-perubahan dalam masyarakat dapat terjadi. Menyesuaikan dengan kondisi pada zamannya. Hal itu disebabkan karena ilmu sosial bersifat dinamis.

\section{KESIMPULAN}

Berdasarkan hasil obsevasi, wawancara, dokumentasi dan studi pustaka mengenai Solidaritas Imigran Madura di Perantauan Desa Jemparing Kecamatan Long Ikis Kabupaten Paser, peneliti menarik kesimpulan secara garis besar sebagai berikut:

1. Kondisi wilayah geografis Kepulauan Madura yang sebagian besar wilayahnya merupakan daerah yang tandus dan kering, menyebabkan intensitas persaingan hidup semakin kuat antar sesama orang Madura. Tidak heran jika melihat orang- orang Madura itu memiliki karakter yang keras dan pantang penyerah. Hal ini berdasar pada kondisi yang mereka hadapi sehari-hari. Inilah yang memunculkan stereotif pada orang Madura bahwa "Orang Madura memiliki watak yang keras". Secara Sosiologis, kondisi akan membentuk watak/karakter seseorang.

2. Faktor pendorong yang menyebabkan Imigran Madura merantau ke Kalimantan Timur adalah tidak lain karena Kalimantan Timur merupakan salah satu propinsi yang memiliki sumber daya alam yang berlimpah, lapangan pekerjaan yang luas serta upah minimum propinsi yang tinggi. 
3. Solidaritas yang terjalin ketika Etnis Madura berada di perantauan jauh lebih kuat dan solid dibanding berada di daerah asal (Madura). Hal itu disebabkan mereka hidup secara homogen (seragam) dalam satu komunitas lingkungan, tentu konflik sosial sedikit dapat dihindari. Berbeda dengan mereka (Etnis Madura) hidup dalam suatu masyarakat yang bersifat heterogen (beragam), tentunya konflik sosial tersebut sangat mungkin bisa terjadi, sebab dalam masyarakat yang heterogen, akan banyak perbedaan yang akan dijumpai dalam hidup bermasyarakat, baik itu bersifat kultur maupun ideologi. Oleh karena itu mereka (Etnis Madura) diharuskan mampu, untuk dapat menyesuaikan diri dengan tempat tinggal mereka pada saat berada di perantauan. Selain itu mereka (Etnis Madura) juga memiliki rasa saling memiliki, tanggung jawab, senasib, dan saling menjaga sesama Etnis Madura di perantauan. Hal ini merupakan ajaran yang telah diturunkan dari nenek moyang/leluhur dan hinggah saat ini masih tetap dipertahankan dan dijalankan.

\section{DAFTAR PUSTAKA}

Bungin, Burhan, 2008, Sosiologi Komunikasi, Kencana Prenada Media Group, Jakarta.

Cangara, Hafiel, 2008, Pengantar Ilmu Komuikasi, PT. Raja Gramedia Persada, Jakarta.

Nasikun, 1989, Sistem Sosial Indonesia, CV Rajawali, Jakarta.Sunarto, Kasmanto, 2004, Pengantar Sosiologi (edisi revisi), Lembaga Penerbit Fakultas Ekonomi Universitas Indoneisa, Jakarta.Soetomo, 2013, Masalah Sosial Dan Upaya Pemecahannya, Pustaka Belajar, Yogyakarta.Wirotomo, Paulus, 2012, Sistem Sosial Indoneisa, Penerbit Universitas Indonesia (UI-Press), Jakarta.

Rujukan dari Jurnal dan Internet "Populasi Suku Madura di Kalimantan ". http://id.m.wikipedia.org/wiki/ Kalimantan. http://id.m.wikipedia.org/wiki/suku-madura. Diakses pada tanggal 19 Desember 2015 "Konflik Dayak dan Madura, Sampit 2001 “. http://id.m.liputan6.com/news/read/goog/dendam-laten-di-bumi-boreno.

Diakses pada tanggal 19 Desember 2015“Dinammika Konflik dan Integrasi Etnis Dayak da Madura “.

Journal.ui.ac.id/index.php/jadi/artikel/viewarticle/3421. Diakses pada tanggal 21 Desember 2015 “Carok Sebagai Elemen Identiti Manusia Madura". Journalarticle.ukm.my.4266/akademika65[02].pdf.

Diakses pada tanggal 21 Desember 2015 “Identitas Madura”. wiyatablogspot. /2008/11/bertahan-dengan-identitas-yangterselip.html.

Diakses pada tanggal 22 Desember 2015 "Interaksi Masyarakat Madura". www.lontarmadura.com/interaksi-sosialorang-madura-rantau/. Diakses pada tanggal 23 Desember 2015 